\title{
Streptococcus pleomorphus sp.nov.: An Anaerobic Streptococcus Isolated Mainly from the Caeca of Birds
}

\author{
By ELLA M. BARNES, C. S. IMPEY, B. J. H. STEVENS \\ AND J. L. PEEL \\ A.R.C. Food Research Institute, Colney Lane, Norwich $N_{4}{ }_{7} U A$ \\ (Received 15 March 1977; revised 28 April 1977)
}

\begin{abstract}
A new species Streptococcus pleomorphus is described. It is obligately anaerobic and classified in the genus Streptococcus because it is a Gram-positive coccus growing in pairs and chains, with a homolactic fermentation of glucose producing L-lactic acid. The GC content of the DNA is $39 \mathrm{~mol} \%$. The organism has been mainly isolated from chickens, turkeys and ducks.
\end{abstract}

\section{INTRODUCTION}

Until recently, Gram-positive anaerobic cocci which occurred in pairs and chains were included in the genus Peptostreptococcus, classified in the seventh edition of Bergey's Manual of Determinative Bacteriology (Breed, Murray \& Smith, 1957) within the family Lactobacillaceae. Rogosa (1971) established a new family Peptococcaceae, containing the genera Peptococcus, Ruminococcus and Peptostreptococcus. This family was defined as containing cocci which did not produce lactic acid as a major fermentation product. Later, in discussing the genus Peptostreptococcus, Rogosa (1974) suggested that organisms which produced lactic acid as a major fermentation product should be included within the genus Streptococcus, a view supported by Holdeman \& Moore (1974). Amongst the anaerobic cocci occurring in pairs and chains which have been isolated by us from poultry, a number have now been shown to produce lactic acid as the major fermentation product. These include groups I and 3 peptostreptococci described by Barnes \& Impey (I970) and the uric acid decomposing strain of Barnes \& Impey (I974).

The group I strains of Barnes \& Impey (I970) are identical with the anaerobic coccus group VIa strains of Hare (I967), and further tests in our laboratory (unpublished data) have confirmed that they have a homolactic fermentation and are aerotolerant, growing equally well in air containing $10 \% \mathrm{CO}_{2}$, hydrogen or hydrogen containing $10 \% \mathrm{CO}_{2}$. In our opinion these bacteria are members of the species Streptococcus intermedius, as defined by Holdeman \& Moore (I974).

In view of the reappraisal of the genus Peptostreptococcus (Rogosa, 1974), we have examined strains of group 3 peptostreptococci (Barnes \& Impey, I970) in an attempt to clarify their taxonomic status. To this end, particular attention was paid to those properties which would justify their inclusion in the genus Streptococcus either as a new species or as one of the aerotolerant or anaerobic species redefined or described by Holdeman \& Moore (1974). At the same time they have been compared with the only existing strain of the anaerobic coccus group VIIa of Hare (I967). The results are presented here. 


\section{METHODS}

Origin of strains. Nine strains, all identified as group 3 peptostreptococci (Barnes \& Impey, 1970), were isolated in these laboratories in a number of different experiments. Strains EBF6I/3IB, EBF6I/60B, EBF6I/66, EBF6I/67, EBF6I/68 and EBF6I/69 were from the caeca of I2-week-old chickens, strain EBDI/3B from the caeca of a duck and strains EBT2/6I and EBT2/68 from the vent area of a frozen turkey carcass. Strain NCTC9808, anaerobic coccus group VII a, was described by Hare (I967).

Strains used for comparison were the group I Peptostreptococcus strain EBF77/25 (Barnes \& Impey, 1970) and the anaerobic coccus group VIa strain NCTC9817 (Hare, 1967), both now identified as Streptococcus intermedius (Holdeman \& Moore, 1974).

The cultures were preserved by freeze-drying (Barnes \& Goldberg, 1962).

Morphological and physiological tests. The majority of tests were carried out using the anaerobic techniques, media and methods described by Barnes \& Impey (1968, 1970). In order to make valid comparisons with those anaerobes, particularly other cocci, which will only grow when strict precautions are taken to eliminate all traces of oxygen from the environment, the primary characterization of the strains was also carried out using the technique of Hungate (1950). Tests included morphological studies, the utilization of certain carbon sources for growth and the analyses for fermentation products. The media and methods used were those described by Barnes \& Impey (1974).

Catalase. The organisms were grown on VL and BGPhlf agar. After 3 days incubation the anaerobic plates were exposed to air for at least $\mathrm{I} h$ and any catalase activity was detected by the formation of gas bubbles after the addition of $3 \%(\mathrm{v} / \mathrm{v}) \mathrm{H}_{2} \mathrm{O}_{2}$ to the colony.

All incubations were at $37^{\circ} \mathrm{C}$ except when otherwise indicated.

Media. The growth media used for the morphological studies or for temporary maintenance of these organisms were as follows: SMIo (Barnes \& Impey, 1974) used with the Hungate technique; VL, modified from Beerens \& Tahon-Castel (1965) by Barnes \& Impey (1968); VL blood agar consisting of VL agar overpoured with a layer of VL agar containing $5 \%(\mathrm{v} / \mathrm{v})$ horse blood; BGP (Barnes \& Impey, 1968) used alone, or supplemented with haemin, liver and chicken faecal extract (BGPhlf) (Barnes \& Impey, 1970); and RCM (Hirsch \& Grinsted, I954).

Serological methods. Antisera of Streptococcus groups A-H, K-S were from Wellcome Research Laboratories. Precipitin tests were carried out as described by Medrek \& Barnes (1962). The organisms were grown in basal medium (Barnes \& Impey, I 968) without agar and containing I \% (w/v) glucose. Before inoculation the medium was held in a boiling water bath for $20 \mathrm{~min}$ to remove oxygen, and the tubes were incubated in an anaerobic jar under hydrogen containing $10 \% \mathrm{CO}_{2}$ for 2 days at $37{ }^{\circ} \mathrm{C}$.

\section{Examination of the products of glucose fermentation}

Growth of the organism. Bacteria were grown in a $500 \mathrm{ml}$ Florence flask containing $200 \mathrm{ml}$ of the following medium ( $\mathrm{g} \mathrm{l}^{-1}$ ): tryptone (Oxoid), 7.5; beef extract (Lab-Lemco, Oxoid), 4; yeast extract (Oxoid), 3 ; cysteine hydrochloride, $0.5 ;$ glucose, $5 ; \mathrm{KH}_{2} \mathrm{PO}_{4}, 4 ; \mathrm{pH} 7 \cdot 2$ to $7 \cdot 4$. The medium was sterilized by autoclaving at I $21^{\circ} \mathrm{C}$ for $15 \mathrm{~min}$, cooled rapidly to $37^{\circ} \mathrm{C}$ and $\mathrm{I} \mathrm{ml}$ of $0.5 \mathrm{M}-\mathrm{NaHCO}_{3}$, (sterilized by autoclaving) was added followed by an inoculum of $4 \mathrm{ml}$ of $\mathrm{I} 6 \mathrm{~h}$ culture grown in VL medium. The flask was placed at $37^{\circ} \mathrm{C}$ and a gassing head was fitted with the outlet connected to a trap containing $20 \mathrm{ml}$ of carbonate-free $2 \mathrm{M}-\mathrm{NaOH}$ to absorb any $\mathrm{CO}_{2}$ produced during the fermentation. A tube of soda lime, at the exit from the trap, prevented ingress of atmospheric $\mathrm{CO}_{2}$. Immediately after inoculation and assembly, hydrogen was bubbled through the medium for $20 \mathrm{~min}$ at approximately $200 \mathrm{ml} \mathrm{min}^{-1}$; the inlet to the gassing head was then closed.

After incubation for $24 \mathrm{~h}, 2 \mathrm{ml}$ of $5 \mathrm{M}-\mathrm{H}_{2} \mathrm{SO}_{4}$ contained in a tube suspended inside the flask was tipped into the culture to release any combined $\mathrm{CO}_{2}$ which was then flushed through the absorber by a slow stream of oxygen-free nitrogen for $\mathrm{I} h$. The flask was then disconnected, the volume of liquid was measured and the bacteria were recovered by centrifuging at $15000 \mathrm{~g}$ for $20 \mathrm{~min}$. The supernatant was kept at $-20^{\circ} \mathrm{C}$ until analysed. The bacteria were washed with distilled water, re-centrifuged and suspended in $5 \mathrm{ml}$ distilled water; samples ( $\mathrm{I} \mathrm{ml}$ ) of this suspension were dried at $\mathrm{I} 10^{\circ} \mathrm{C}$ for $24 \mathrm{~h}$ to determine the dry weight.

Analysis of culture supernatants. (i) Glucose was estimated with glucose oxidase following the manufacturer's instructions (Boehringer GOD-Perid method).

(ii) Carbon dioxide absorbed by the $\mathrm{NaOH}$ in the trap was estimated manometrically by liberation with acid. A sample of the original $2 \mathrm{~m}-\mathrm{NaOH}$ solution which had been kept stoppered throughout the incubation and a sample from the uninoculated medium were used as controls.

(iii) Volatile fatty acids were separated from the fermentation supernatant by the steam distillation method of Annison (1954) but with a distillation rate of approximately $500 \mathrm{ml} \mathrm{h}^{-1}$. Two $40 \mathrm{ml}$ portions of distillate were collected and each titrated under $\mathrm{CO}_{2}$-free conditions using $\mathrm{o} \cdot \mathrm{I} \mathrm{M}-\mathrm{NaOH}$ from a microburette 
(Manostat Corporation, New York, U.S.A.) and phenol red indicator. After titration, a further $0.2 \mathrm{ml}$ of $0.1 \mathrm{M}-\mathrm{NaOH}$ was added to each portion; these were then combined and evaporated to dryness. Before separation of the individual acids, $0.1 \mathrm{ml}$ of $n$-hexanoic acid $[2 \%(\mathrm{w} / \mathrm{v})$ in an aqueous solution of acetone $(40 \%, v / v)$ ] was added as an internal standard to the dried sodium salts. Approximately $20 \%$ excess of

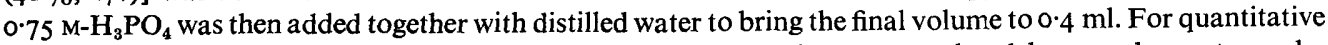
separation of the volatile acids other than formate, I $\mu \mathrm{l}$ samples were analysed by gas chromatography using a dual flame ionization detector and a glass column ( $1 \cdot 5 \mathrm{~m} \times 4 \mathrm{~mm})$ packed with polyethylene glycol $20 \mathrm{M}(20 \%, \mathrm{w} / \mathrm{v})$ on $100 / 120$ mesh Diatomite $\mathrm{C}$, washed with $\mathrm{H}_{3} \mathrm{PO}_{4}(2 \%, \mathrm{w} / \mathrm{v})$. The column temperature was $145{ }^{\circ} \mathrm{C}$, detector temperature $200{ }^{\circ} \mathrm{C}$ and the carrier gas was argon flowing at $50 \mathrm{ml} \mathrm{min}^{-1}$. The concentrations of individual acids, except formic acid to which the detectors were insensitive, were determined from the ratios of their peak areas to that of the internal standard, corrected by previously determined detector response factors. For the determination of formate, the following reagents were added to the dried sodium salts: $0 . \mathrm{I} \mathrm{ml}$ of $\mathrm{I} \%(\mathrm{w} / \mathrm{v})$ tetradecane in acetone, as an internal standard; $50 \%$ excess of $0.5 \mathrm{M}$-dichloroacetic acid in acetone (Shelley, Salwin \& Horwitz, 1963); and acetone to bring the total volume to $0.5 \mathrm{ml}$. Samples ( $\mathrm{I} \mu \mathrm{l}$ ) were analysed by gas chromatography using a ${ }^{90} \mathrm{Sr}$-argon ionization detector and a glass column $(1 \cdot 3 \mathrm{~m} \times 4 \mathrm{~mm})$ with the packing described above. The column temperature was $100{ }^{\circ} \mathrm{C}$ and the flow rate of argon carrier gas was $50 \mathrm{ml} \mathrm{min}^{-1}$.

(iv) Total lactic acid was estimated by the ceric sulphate method of Elsden \& Gibson (1954).

(v) L-Lactic acid was estimated by the method of Grey, Jones \& Robinson (1974) using L-lactate dehydrogenase (cytochrome $b_{2}$ ).

(vi) Succinic acid in culture supernatants $(20 \mathrm{ml})$ was extracted with celite and ether by the method of Knight (1962) for the recovery of lactate during malate degradation. After evaporation of the ether, the residue was dissolved in $0.4 \mathrm{ml}$ water and succinic acid was estimated polarographically in the apparatus

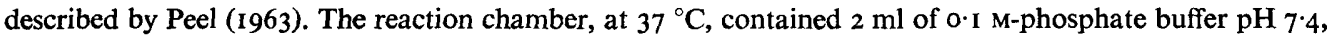
I $\mathrm{ml}$ crude succinic oxidase from pig heart (Umbreit, Burris \& Stauffer, 1964), and $3 \mathrm{ml}$ distilled water. After equilibration, $0.04 \mathrm{ml}$ of dissolved residue was added and the oxygen uptake was compared with that caused by the addition of the same volume of $0.02 \mathrm{M}$-succinic acid.

DNA base composition. Cultures were grown as described for the glucose fermentation experiments except that the medium and inoculum were increased sixfold and the gas phase was nitrogen. Growth was measured turbidimetrically on samples withdrawn through a port in the gassing head, under a flow of nitrogen. Cultures in the late-exponential phase of growth $(24 \mathrm{~h})$ were harvested by centrifugation and washed twice with saline/EDTA solution (containing $0.15 \mathrm{M}-\mathrm{NaCl}$ and $0.1 \mathrm{M}-\mathrm{EDTA}, \mathrm{pH} \mathrm{8} \cdot 0$ ). Bacteria were disrupted in a press (Hughes, 195I) and then heated at $70^{\circ} \mathrm{C}$ for $15 \mathrm{~min}$ in saline/EDTA containing $3 \%(w / v)$ sodium dodecyl sulphate. The method of Marmur (196I) was then used with the following modifications. Three ribonuclease treatments were given at $37^{\circ} \mathrm{C}$ for $0.5 \mathrm{~h}$, using ribonuclease $\mathrm{TI}_{\mathrm{I}}$ in addition to ribonuclease I (Saito \& Miura, 1963). After each treatment, $\mathrm{NaCl}$ and heat-treated protease (Sigma type VI) (Hotta \& Bassel, 1965) were added for $\mathrm{i} \mathrm{h}$ at $45^{\circ} \mathrm{C}$ ( $\mathrm{I} \mathrm{mg}$ protease preparation per $\mathrm{ml}$ nucleic acid solution for the first treatments; $100 \mu \mathrm{g} \mathrm{ml}^{-1}$ for the second and third treatments). After the first two protease treatments a single deproteinization was done but after the third treatment the procedure of Marmur was followed, with further deproteinization and one final precipitation using propan-2-ol. The precipitated DNA was dried with ethanol and dissolved in $0.15 \mathrm{M}-\mathrm{NaCl}$ plus $0.015 \mathrm{M}$-trisodium citrate.

To determine $T_{m}$, samples of this solution with an initial $E_{260}^{1 \mathrm{~cm}}$ of approximately 0.5 , were heated electrically in semi-micro cuvettes from 77 to $97{ }^{\circ} \mathrm{C}$ at $0.2{ }^{\circ} \mathrm{C} \mathrm{min}-1$. The temperature was measured by a calibrated thermocouple sealed into the Tefion stopper and positioned just above the light path. Values of transmittance and thermocouple e.m.f. were logged every $20 \mathrm{~s}$ on a punched paper tape by a Solartron Data Transfer Unit having a digital voltmeter type LM I604 and a Facit 4070 paper tape punch. Absorbance relative to that at $25^{\circ} \mathrm{C}$ and temperature in ${ }^{\circ} \mathrm{C}$ were obtained by a Fortran program run on an IBM II 30 computer. These values were plotted by an IBM I 627 plotter to produce a denaturation curve from which the $T_{m}$ was measured and the base ratio (as mol \% GC) was calculated according to the equation: mol \% GC $=\left(T_{m}-69 \cdot 37\right) / 0.4 \mathrm{I}$ (De Ley, 1970). DNA from Escherichia coli B (Sigma type VIII) was used as a standard and gave a value of $90.9 \pm 0.3^{\circ} \mathrm{C}$ [mean of I I determinations compared with published values of $89 \cdot 7$ to $9 \mathrm{I} \cdot 5^{\circ} \mathrm{C}$ (Colwell \& Mandel, I964; Hoyer \& McCullough, 1968; De Ley, 1970)]. 


\section{RESULTS}

The group 3 peptostreptococci (Barnes \& Impey, 1970) studied in this paper occurred in the avian caeca at $>10^{7} \mathrm{~g}^{-1}$. They were obligate anaerobes, being unable to grow on an optimal growth medium (BGPhlf agar) when incubated in air or air containing $10 \% \mathrm{CO}_{2}$, but they could be isolated under anaerobic conditions which would not permit growth of the more fastidious anaerobes which considerably outnumbered them in the caecum. Selective media have not been developed for their isolation but some strains, including EBF6I/6OB, were recovered on the ethyl violet azide medium developed by Barnes \& Goldberg (1962) for the isolation of Bacteroides hypermegas. Subsequent tests showed that they could not be recovered quantitatively and growth of some strains was inhibited on this medium. Other strains were isolated on VL blood agar containing Ioo $\mu \mathrm{g}$ kanamycin sulphate $\mathrm{ml}^{-1}$ (Bayer Products Co., Surbiton-upon-Thames, Surrey).

\section{Morphology and cultural characteristics}

The nine strains of group 3 peptostreptococci and the anaerobic coccus group VII a strain (NCTC9808) were all characterized by extreme pleomorphism and variations in cell size. Typical cocci in pairs and chains occurred in some media whilst in other media they were always coccobacillary. Whether this pleomorphism depends on media constituents or the anaerobic conditions used has not been established. An example of the differences obtained can be seen in Fig. I where the same $24 \mathrm{~h}$ culture of EBF6I/60B was used to inoculate VL broth, subsequently incubated for $24 \mathrm{~h}$, SMIo broth, incubated for $24 \mathrm{~h}$ (using the Hungate technique), and a BGPhlf agar plate, incubated under hydrogen containing $10 \% \mathrm{CO}_{2}$ for 3 days. No capsules were observed. The organisms were Grampositive in very young cultures, often becoming Gram-negative within $24 \mathrm{~h}$.

All strains grew well in RCM, VL or BGP liquid media without supplements (see Methods). After 3 days incubation, colonies on agar media such as RCM, BGPhlf, VL or VL blood agar were about 2 to $3 \mathrm{~mm}$ in diameter, had an irregular edge and were cream. On the VL blood agar, $\beta$-haemolysis was sometimes noted but appeared to be a variable character.

\section{Serology}

The group 3 Peptostreptococcus strain EBF6I/60B and the anaerobic coccus group VII a strain (NCTC9808) were tested serologically (see Methods) and found to have no reaction with antisera of Streptococcus groups A-H, K-S; there was a slight reaction with group $\mathrm{O}$ antiserum.

\section{Physiological properties}

The physiological properties are listed in Table $I$ and in the description of the species given below.

Although carbohydrates were required for growth only a few were utilized, in particular glucose, fructose and usually mannose. Tests carried out by Barnes \& Impey (1972) using strain $\mathrm{EBF} 6 \mathrm{I} / 6 \mathrm{OB}$ and substrates of possible ecological importance in the avian caecum, showed no activity against dextran, xylan, starch, amorphous cellulose, tributyrin, casein, chondroitin sulphate, uric acid, deoxyribonucleic and ribonucleic acids; but weak pectinolytic activity was observed.

\section{Glucose metabolism}

A detailed study of the glucose metabolism of strain EBF6r/6oB showed that the main fermentation product was L-lactic acid, formed in sufficient amount to account for all the glucose utilized (Table 2). Carbon dioxide, formic, acetic, $n$-butyric and succinic acids were produced but in much smaller amounts and may well have been derived from substrates other than glucose in the complex medium. This would be in accord with the high overall recovery of carbon in the products. 

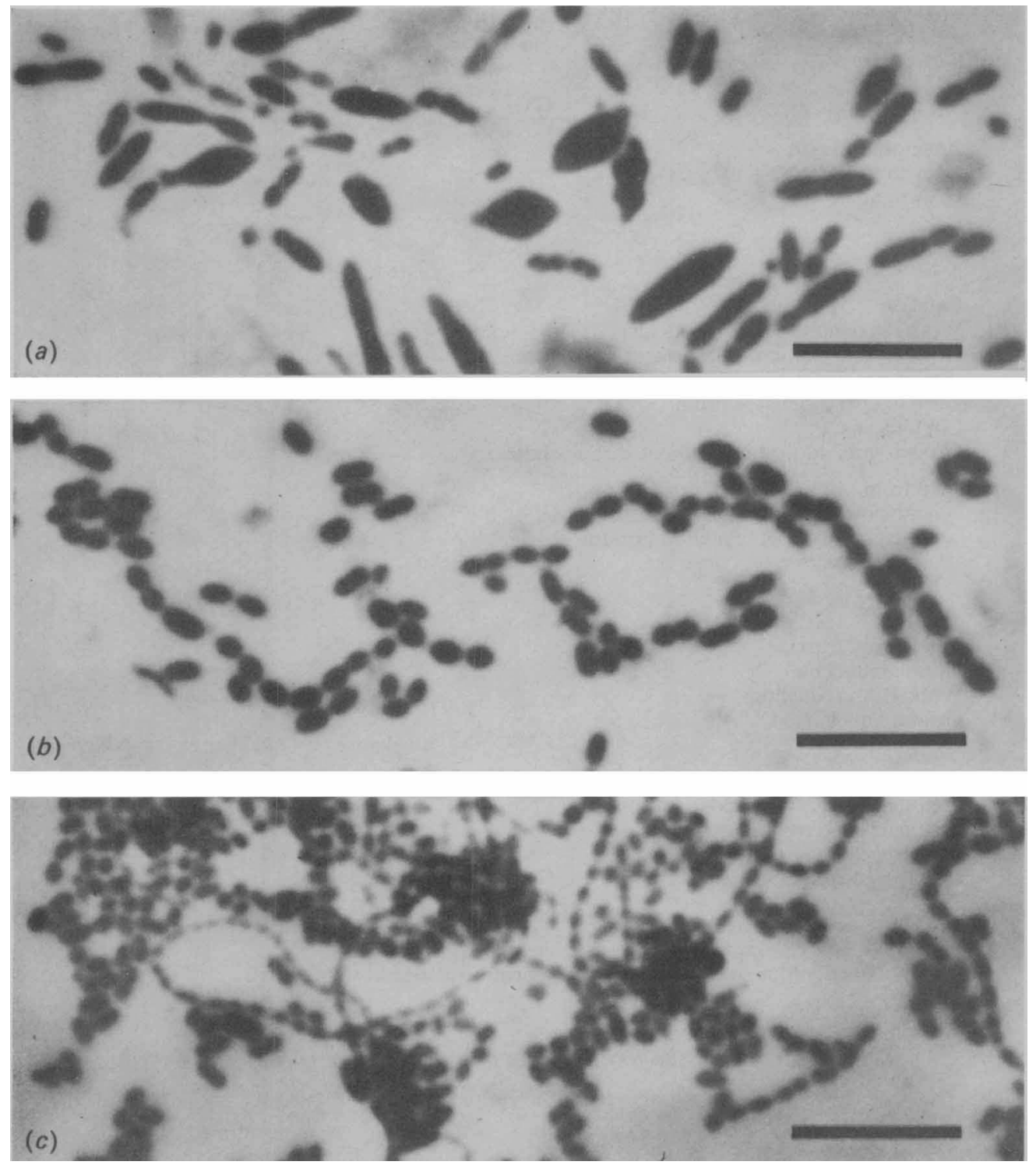

Fig. I. Streptococcus pleomorphus strain EBF6I/60в: (a) grown in VL broth for $24 \mathrm{~h}$; $(b)$ grown in SMIo broth for $24 \mathrm{~h}$ (using the Hungate technique); $(c)$ grown on a BGPhlf agar plate for 3 days (under hydrogen containing $10 \% \mathrm{CO}_{2}$ ). Bar markers represent $5 \mu \mathrm{m}$.

The fermentation products formed by the other nine strains, including the group VII a strain (NCTC9808) were examined by semi-quantitative methods. The earlier tests involved the use of paper chromatography (Barnes \& Impey, 1968) whilst subsequent tests were carried out using gas-liquid chromatography (Barnes \& Impey, 1974). In all strains lactic acid was the major product; small amounts of butyric and formic acids were found and in some strains acetic acid was also detected. Quantitative examination of the lactic acid produced by all these strains showed that it was always the $\mathrm{L}(+)$ form and accounted for 50 to $80 \%$ of the glucose carbon utilized according to the strain. 
Table I. Properties of 10 strains included in the new species $S$. pleomorphus

No. of strains

Anaerobic growth

Growth in air or air $+10 \% \mathrm{CO}_{2}$

Growth at

$45^{\circ} \mathrm{C}$
$37^{\circ} \mathrm{C}$
$20^{\circ} \mathrm{C}$

Catalase

Weak $\beta$-haemolysis (VL blood agar)

Glucose fermentation (L-lactic acid as the sole major product)

Terminal pH in glucose broth

Copious gas

Growth in basal medium without carbohydrate

Acid from

Arabinose, cellobiose, dextrin $\dagger$, galactose,

lactose, maltose, mannitol, inositol, salicin, starch, sucrose or xylose

Fructose
Mannose

Indole production

Nitrate reduction

Weak $\mathrm{H}_{2} \mathrm{~S}$ production

Gelatin liquefaction

Cysteine milk

Growth in presence of

Brilliant green ( $\mathrm{I} / \mathrm{I} 00000)$

Kanamycin (100 $\mu \mathrm{g} \mathrm{ml}^{-1}$ )

Neomycin ( $100 \mu \mathrm{g} \mathrm{ml}^{-1}$ )

Polymyxin B (10 $\mu \mathrm{g} \mathrm{ml}^{-1}$ )

\begin{tabular}{|c|c|c|}
\hline $\begin{array}{c}\text { Hare } \\
\text { group VIIa } \\
\text { (NCTC9808) }\end{array}$ & $\begin{array}{l}\text { Group 3 } \\
\text { peptostrepto- } \\
\text { cocci }\end{array}$ & $\begin{array}{c}\text { Type strain } \\
\text { EBF61/6o B } \\
\text { (NCTCI 1087) }\end{array}$ \\
\hline I & 9 & I \\
\hline+ & + & + \\
\hline- & - & - \\
\hline $\mathrm{NT}$ & + & + \\
\hline+ & + & + \\
\hline $\mathrm{NT}$ & - & - \\
\hline - & - & - \\
\hline- & $+(4 / 9)^{*}$ & + \\
\hline+ & + & + \\
\hline $4 \cdot 6$ & $4 \cdot 4-5 \cdot 0$ & $4 \cdot 6$ \\
\hline$\overline{-}$ & $\begin{array}{l}- \\
-\end{array}$ & 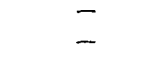 \\
\hline - & - & - \\
\hline+ & + & + \\
\hline$v$ & $+(3 / 5)$ & + \\
\hline- & - & - \\
\hline - & $-\dagger$ & - \\
\hline+ & $+(8 / 9)$ & + \\
\hline- & - & - \\
\hline No change & No change & No change \\
\hline NT & $+(8 / 9)$ & + \\
\hline+ & $+t$ & + \\
\hline+ & $+\dagger$ & + \\
\hline NT & + & + \\
\hline
\end{tabular}

NT, Not tested; + , positive; - , negative; $v$, variable for the same strain.

* No. of strains giving the reaction shown.

$\dagger$ Only four strains of the group 3 peptostreptococci were tested.

Table 2. Products of the fermentation of glucose by $S$. pleomorphus strain EBF6I/60B

$\begin{array}{lc}\text { Product } & \begin{array}{c}\text { Amount formed } \\ \text { [mmol (mol glucose } \\ \text { fermented) }\end{array} \\ \text { Carbon dioxide } & 124 \\ \text { Formic acid } & 114 \\ \text { Acetic acid } & 8 \\ n \text {-Butyric acid } & 64 \\ \text { Lactic acid } & 2000 \\ \text { Succinic acid } & 10 \\ \text { Molar growth yield } & 25 \\ \text { [g dry wt (mol glucose) }^{-1} \text { ] } & \\ \text { Carbon recovery }(\%) & 109\end{array}$

* All the glucose initially present was utilized and no products other than those indicated were detected. 
Table 3. Differential properties of S. pleomorphus sp.nov., S. hansenii, $S$. intermedius, $S$. constellatus and $S$. morbillorum

S. pleomorphus

Aerotolerance

Acid from

Cellobiose

Dextrin

Fructose

Galactose

Glucose

Lactose

Maltose

Mannose

Salicin

Starch

Sucrose

Cysteine milk

$\mathrm{H}_{2} \mathrm{~S}$ production

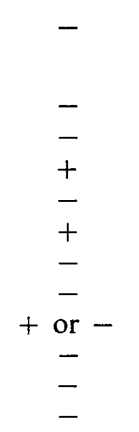

No change w
S. hansenii*

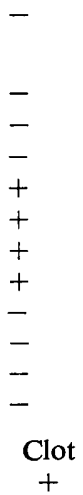

S. intermedius $\dagger$

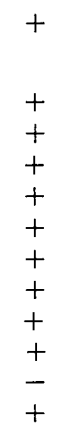

Acid, clot
S. constellatus* S. morbillorum*
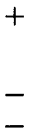

$-$

$-$

W

-

W

$-$

w

No change No change

+ , Positive (for acid formation, $\mathrm{pH}$ below 5.5 ); w, weak positive (for acid formation, $\mathrm{pH} 5.5$ to 6.0 ); - , negative; $w-$, variable for the same strain.

* Type strains of Holdeman \& Moore (1974).

$\dagger$ Type strain (Holdeman \& Moore, 1974) and strains EBF77/25 and NCTC9817.

\section{DNA base ratio}

Four determinations on DNA from strain EBF6I/60B gave $T_{m}$ values of $85.9,85.6$ and $85.2{ }^{\circ} \mathrm{C}$ (average $85.5^{\circ} \mathrm{C}$ ) corresponding to a GC content of $39.4 \mathrm{~mol} \%$, compared with a $T_{m}$ value of $90.9{ }^{\circ} \mathrm{C}$ for $E$. coli B (GC content $52.8 \mathrm{~mol} \%$ ).

\section{DISCUSSION}

The results indicate that the organisms previously designated group 3 peptostreptococci (Barnes \& Impey, 1970) together with the group VIIa anaerobic coccus (NCTC9808) of Hare (1967) belong to the genus Streptococcus rather than to the genera Peptostreptococcus, Ruminococcus or the recently described Coprococcus (Holdeman \& Moore, 1974) because of their homolactic fermentation with the production of L-lactic acid. The GC content of the DNA (39 mol \%) is within the range ( 32 to $42 \%$ ) reported for other members of the genus (Deibel \& Seeley, 1974). The organisms are strict anaerobes, all the strains isolated so far being unable to grow on an optimal growth medium in air or air containing $10 \%$ $\mathrm{CO}_{2}$. In this and other respects they are unlike Streptococcus intermedius, Streptococcus constellatus or Streptococcus morbillorum now classified by Holdeman \& Moore (1974) in the genus Streptococcus, and also differ from the new anaerobic species Streptococcus hansenii described by Holdeman \& Moore (1974). They are considered sufficiently different from these four species to warrant the creation of a new species named Streptococcus pleomorphus; some of their differential properties are shown in Table 3. Apart from the unusual morphology, other differences include the failure of $S$. pleomorphus to ferment sucrose, maltose, galactose and lactose.

The nine strains isolated from poultry and previously designated group 3 peptostreptococci, together with the group VIIa anaerobic coccus (NCTC9808) isolated by Hare (I967) from human faeces, belong to the proposed new species $S$. pleomorphus described below. 


\section{Streptococcus pleomorphus sp.nov.}

\section{(pleo.mor'phus. Gr. adj. pleomorphus many forms)}

Pleomorphic cocci, occurring singly, in pairs and short chains; size and shape may vary considerably according to the medium and conditions of growth (Fig. I). Gram-positive in young cultures, often becoming Gram-negative within $24 \mathrm{~h}$. On optimal growth media such as RCM, BGPhlf or VL agar, after incubation for 3 days, colonies are about 2 to $3 \mathrm{~mm}$ in diameter, circular, convex and with an irregular edge. On VL blood agar some strains may be weakly $\beta$-haemolytic. Growth in broth is flocculent.

Anaerobic, no growth occurring in air or air containing $10 \% \mathrm{CO}_{2}$. No growth at $20{ }^{\circ} \mathrm{C}$, good growth at 37 and $45^{\circ} \mathrm{C}$. Catalase negative.

Carbohydrates are required for growth. The terminal $\mathrm{pH}$ varies between about 4.4 and $5 \cdot$. Glucose is fermented by homolactic fermentation to L-lactic acid. Gas is not produced. Traces of butyric, formic and sometimes acetic and succinic acids are also found.

Acid is produced from glucose, fructose and usually mannose. No acid is produced from arabinose, cellobiose, dextrin, galactose, inositol, lactose, maltose, mannitol, salicin, starch, sucrose or xylose. There is no change in cysteine milk, gelatin is not liquefied, indole is not produced, and nitrates are not reduced. Small amounts of $\mathrm{H}_{2} \mathrm{~S}$ are detected in media containing ferrous sulphate and sodium thiosulphate.

Growth occurs in the presence of polymyxin B (Io $\left.\mu \mathrm{g} \mathrm{ml}^{-1}\right)$, neomycin $\left(100 \mu \mathrm{g} \mathrm{ml}^{-1}\right)$, kanamycin (I00 $\mu \mathrm{g} \mathrm{ml}^{-1}$ ) and most strains are resistant to brilliant green (I/I00000).

Source: the intestines of poultry and occasionally human faeces.

Type strain. NCTCI 1087 (= EBF61/60B). The GC content of the DNA of the type strain is $39 \mathrm{~mol} \%$ (by $T_{m}$ ).

We are grateful to Mrs S. M. Ring of the John Innes Institute/Food Research Institute computer group for writing and running the computer program.

\section{REFERENCES}

Annison, E. F. (1954). Studies on the volatile fatty acids of sheep blood with special reference to formic acid. Biochemical Journal 58, 670680 .

Barnes, E. M. \& GoldberG, H.S. (1962). The isolation of anaerobic Gram-negative bacteria from poultry reared with and without antibiotic supplements. Journal of Applied Bacteriology 25, 94-106.

BARNES, E. M. \& IMPEY, C. S. (I968). Anaerobic Gram-negative non-sporing bacteria from the caeca of poultry. Journal of Applied Bacteriology 31, 530-541.

BARNES, E. M. \& IMPEY, C. S. (I970). The isolation and properties of the predominant anaerobic bacteria in the caeca of chickens and turkeys. British Poultry Science rI, 467-48I.

BARNES, E. M. \& IMPEY, C. S. (I972). Some properties of the non-sporing anaerobes from poultry caeca. Journal of Applied Bacteriology 35, 24I$25 I$.

BARNES, E. M. \& IMPEY, C. S. (1974). The occurrence and properties of uric acid decomposing anaerobic bacteria in the avian caecum. Journal of Applied Bacteriology 37, 393-409.

BeERENS, H. \& TAHON-CASTEL, M. (1965). Infections Humaines à Bactéries Anaérobies non Toxigènes, p. 13. Brussels : Presses Académiques Européennes.
Breed, R. S., Murray, E. G. D. \& Smith, N. R. (editors) (1957). Bergey's Manual of Determinative Bacteriology, 7 th edn. Edinburgh \& London: Livingstone.

Colwell, R. R. \& Mandel, M. (1964). Adansonian analysis and deoxyribonucleic acid base composition of some Gram-negative bacteria. Journal of Bacteriology 87, 1412-1422.

Deibel, R. H. \& Seeley, JR, H. W. (I974). Genus I Streptococcus Rosenbach i 884 . In Bergey's Manual of Determinative Bacteriology, 8th edn, pp. 490-509. Edited by R. E. Buchanan and N. E. Gibbons. Baltimore: Williams \& Wilkins.

DE LEY, J. (1970). Re-examination of the association between melting point, buoyant-density and chemical base composition of deoxyribonucleic acid. Journal of Bacteriology ror, 738-754.

Elsden, S. R. \& Gibson, Q. H. (I954). The estimation of lactic acid using ceric sulphate. Biochemical Journal 58, I 54-I 58.

Grey, T. C., Jones, J. M. \& Robinson, D. S. (I974). The influence of death struggle on the rate of glycolysis in chicken breast muscle. Journal of the Science of Food and Agriculture 25, 57-66.

HARE, R. (1967). The anaerobic cocci. In Recent Advances in Medical Microbiology, pp. 284-317. Edited by H. P. Waterson. Boston: Little Brown \& Co. 
Hirsch, A. \& Grinsted, E. (1954). Methods for the growth and enumeration of anaerobic sporeformers from cheese, with observations on the effect of nisin. Journal of Dairy Research 21, IOI-I IO.

Holdeman, L. V. \& Moore, W. E. C. (I974). New genus, Coprococcus, twelve new species, and emended descriptions of four previously described species of bacteria from human faeces. International Journal of Systematic Bacteriology 24, 260-277.

HotTA, Y. \& Bassel, A. (1965). Molecular size and circularity of DNA in cells of mammals and higher plants. Proceedings of the National Academy of Sciences of the United States of America 53, 356-362.

Hoyer, B. H. \& MCCullough, N. B. (1968). Polynucleotide homologies of Brucella deoxyribonucleic acids. Journal of Bacteriology 95, 444448.

Hughes, D. E. (195I). A press for disrupting bacteria and other micro-organisms. British Journal of Experimental Pathology 32, 97-109.

Hungate, R. E. (1950). The anaerobic mesophilic cellulolytic bacteria. Bacteriological Reviews r4, I-49.

KNIGHT, M. (1962). The photometabolism of propionate by Rhodospirillum rubrum. Biochemical Journal 84, I70-I85.

MARMUR, J. (I96I). A procedure for the isolation of deoxyribonucleic acid from micro-organisms. Journal of Molecular Biology 3, 208-2 18.
MedreK, T. F. \& Barnes, E. M. (1962). The influence of the growth medium on the demonstration of a group D antigen in faecal streptococci. Journal of General Microbiology 28, 70 I-709.

PeEL, J. L. (1963). The catalysis of the auto-oxidation of 2-mercaptoethanol and other thiols by vitamin $B_{12}$ derivatives. Polarographic and other investigations. Biochemical Journal 88, 296-308.

Rogosa, M. (I97I). Peptococcaceae, a new family to include the gram-positive, anaerobic cocci of the genera Peptococcus, Peptostreptococcus and Ruminococcus. International Journal of Systematic Bacteriology 21, 234-237.

Rogosa, M. (I974). Family III. Peptococcaceae. In Bergey's Manual of Determinative Bacteriology, 8th edn, pp. 517-528. Edited by R. E. Buchanan and N.E. Gibbons. Baltimore: Williams \& Wilkins.

Saito, H. \& Miura, K. I. (I963). Preparation of transforming deoxyribonucleic acid by phenol treatment. Biochimica et biophysica acta 72, 619629.

Shelley, R. N., Salwin, H. \& Horwitz, W. (1963). Quantitative determination of formic, acetic, propionic and butyric acids by gas chromatography. Journal of the Association of Official Analytical Chemists 46, 486-493.

Umbreit, W. W., Burris, R. H. \& Stauffer, J. F. (I964). Manometric Techniques, 4th edn, p. 195. Minneapolis: Burgess Publishing Co. 